\title{
Identity Quest between Trauma and Survival: A critical study of Margaret Atwood's Fiction
}

\begin{abstract}
Mai Mohamed Batroukha
Abstract

Survival theme is a dominant theme in Margaret Atwood novels, she is obsessed with this theme in all her works. Her protagonists seek survival in all its possible vents and shapes. Also, they keep trying to overcome all the obstacles to achieve their survival. Their attempts result either in failure or in marginal success but they keep trying. All of Atwood's protagonists are already aware of their problems and they insist on getting rid of this problem by searching for self-knowledge and trying to realize their identity. Atwood is crafted in weaving rituals of survival in her fiction whether thematically or technically. So, in this paper both rituals will be discussed through analyzing some of Atwood's Novels, Surfacing (1972), Bodily Harm(1981),The Handmaids Tale(1985), and Cats Eye (1988). Thematically, Atwood introduces connections between woman and nature through an eco-feminist perspective which has been clearly depicted in Surfacing (1972). With great craft she weaves together image patterns and themes that draw spontaneous eco-critical attention. Subjugation of woman in a patriarchal society and exploitation of nature in a capitalistic society are the themes which Atwood has quite often taken up for her writings. Technically, through multi narratives, one can see the topic from another point of view, or it can be solved from other perspectives as a critical insight to the inner character which is very clear in both Cats Eye and the Handmaid's Tale.

Atwood's protagonists struggle to realize why they are dissatisfied with their lives and the world around them. They cannot adapt easily with the society they live in. Some go beyond realization of victimization, others try rejection, and some miss but most survive. All of them use one common factor which is creativity, everyone creates her own ritual of survival in a very creative way. All of them are women in typical victimized situations who refuse to accept their victimization and do what they can to fight this situation. Atwood in her novels seeks happy endings for her victimized female figures. So, through rituals of survival, they achieved their survival whether psychologically or psychically, which consequently leads to their happiness by their new life perspective.
\end{abstract}

\section{Chapter four:}

Rituals of survival:

In her 1972 study of Canadian literature, aptly titled Survival, Margaret Atwood uses the symbol of the mirror to describe the difficulty faced by Canadian writers and artists, struggling to assert their voices in a country trying to state itself against a colonial past. Here, she sees Canada as compressed between the overwhelming, colonizing powers of Great Britain on one side, and The United States on the other. In her view, a piece of art becomes a mirror. As she writes in her Survival: 
If a country or a culture lacks such mirrors it has no way of knowing what it looks like; it must travel blind. If, as has long been the case in Canada, the viewer is given a mirror that reflects not him but someone else, and told at the same time that the reflection he sees is himself, he will get a very distorted idea of what he is really like. He will also get a distorted idea of what other people are like: it's hard to find out who anyone else is until you have found out who you are. $(15-16)$

Atwood's novels are examined in many contexts whether cultural historical or even social, which explores the victimization of women. Victimization includes anything that affects women's survival, specifically, victimization through physical, psychological, and economic manipulation. Survival is also taken in the broadest sense. It includes both physical and spiritual survival "as anything more than a minimally human being" (Survival 33). In Survival, Atwood presents four "Basic Victim Positions," which include denying victimization, acquiescing in victimization, repudiating victimization, and becoming a creative nonvictim" (36-39). Recognition of victimization deals with Atwood's initial two " positions " when a woman admits that she is a victim. Rejection of being a victim is concerned with Atwood's final two "positions" when a victim learns to fight victimization, and perhaps, succeeds well enough to live as a fully functioning, "creative non-victim" ( Survival 38).

Terms like 'victimization', 'survival', and 'struggle' seem to be politically biased, but Atwood masterfully shows how these terms are not hyperbolic. She explicates that women are systemically victimized and must struggle to survive psychologically and even physically. For example, Atwood portrays many female characters who are sabotaged psychologically by civil living. The civil deterioration they experience is not necessarily in the form of physical blight, although Atwood is very tough in her descriptions of surrounding environment. The physical plight is seldom referred to, for it appears to be more a result than a cause of the social decay with which Atwood is concerned. The stress caused by the social and economic deviation that surrounds Atwood's characters forces them to fall back into themselves or lash out at others. Urban living offers these characters few escapes from lifestyles that force them into victim roles.

Thus, the dominant theme in Atwood's fiction is survival. Atwood theorizes that the dominant image in Canadian fiction is survival: 
the main idea is the first one: hanging on, staying alive. Canadians are forever taking the national pulse like doctors at a sickbed: the aim is not to see whether he will live at all. Our central idea is one which generates not the excitement and sense of adventure or danger which The Frontier holds out but an almost intolerable anxiety. Our stories are likely to be tales not of those who made it but of those who made it back, from the awful experience the North, the snow-storm, the sinking ship that killed everyone else.( Survival 16)

Margaret Atwood is obsessed with survival in her novels. Her protagonists seek survival in all its possible vents and shapes. Also, they keep trying to overcome all the obstacles to achieve their survival. Their attempts result either in failure or in marginal success, As Atwood explains," the main idea is hanging on, staying alive...this above all, to refuse to be victim" (Atwood, Surfacing 119). So the characters in all of Atwood's novels are already aware of their problems and they insist on getting rid of this problem by searching for self knowledge and trying to realize their identity. She asserts this point in her Survival: "without that knowledge we will not survive." (Survival 27)

Robin Mathews says that there is no doubt that survival is a current motif and a common theme in the Canadian literary tradition. Margaret Atwood, who has made a survey of Canadian people from the thirties to the seventies concludes that:

Survival is a multifaceted and adaptable idea. For early explorers and settlers, it meant bare survival in the face of "hostile" elements and/or natives: carving out a place and a way of keeping alive. But the word also can suggest survival of crisis or disaster, like a hurricane or wreck, and many Canadian poems have this of survival as a theme. (Survival 41)

Survival as a main theme may be a result of many reasons .It may be because of the male oppression, the aggressiveness of society, the new technological uses and their bad effects upon the human race. Many of Atwood's novels discuss major topics that dominate the society like alienation, the fragmentation of the characters, depression, madness, suicide and many other psychological problems. Therefore, these novels illustrate the protagonists simply refuse to be threatened out of their lives. 
Survival, also, has a strong relation with time because it refuses the process of continuing to exist and how to overcome the obstacles,

A preoccupation with one's survival is necessarily also a preoccupation with the obstacles to that survival. In earlier writers these obstacles are externals-the land, the climate, and so forth. In later writers the obstacles tend to become both harder to identify and more internal; they are no longer obstacles to physical survival but obstacles to what we may call spiritual survival, to life as anything more than a minimally human being. Sometimes fear of these obstacles become itself the obstacles, and a character is paralyzed by terror...It may even be life itself that he fears; and when life becomes a threat to life, you have a moderately vicious circle. (Survival 33)

Atwood is crafted in weaving rituals of survival in her fiction whether thematically or technically. So in this chapter both rituals will be discussed. Thematically, Atwood introduces connections between woman and nature through an eco-feminist perspective which has been clearly depicted in Surfacing (1972). Throughout this novel the unnamed narrator begins the novel searching for her missing father and suffering from tragic memories with abortion and being alone and ends with her diving into the lake as a new beginning and new identity for her. So she became one with nature as a ritual of survival.

Atwood is crafted in weaving layers and narratives in her novels. Her novels are easily understandable on a surface level. On another level, she is also a difficult writer whose texts are multi layered. This multilayered fiction is narratively mysterious. However, Atwood's well-crafted narration urges the reader to find his/her way out of the mystery and also evokes the readers' emotions to sympathize with the protagonists and their journey towards survival. Alice M. Palumbo explains this point further when she claims that,

In her novels, Atwood has made constant use of the double voice, depicting characters at war with themselves and their environments. Through inter textual allusions, alterations in narrative point of view, and the use of the unconscious, Atwood shows the way in which the self is constructed from contradictory impulses, some more societally acceptable than others. (21) 
Multiple voices co-exist beautifully in Atwood's novels, she is, after all, a master of the many tongued narrative. Here the Canadian writer shows not only her extraordinary grip on language but also her skillful handling of mixed narrative strategies to build up her central characters that happens to be survivors at the end of the novels. The firstperson narrator is a discursive structure that Atwood uses in several of her novels parts of The Edible Woman (1969); Surfacing (1972); Lady Oracle (1976); The Handmaid's Tale (1985); Cat's Eye (1988); Alias Grace (1996) and Blind Assassin (2000).

The focal point in her novels is to show that her protagonists are not passive and static objects to be acted upon, but dynamic subjects who can choose their future and situate themselves in the appropriate norm. Through multi narratives, one can see the topic from another point of view, or it can be other perspectives as a critical insight to the inner character, which creates a harmony between the novel and the reader to feel that character must survive. It makes the reader find ways in subplots or in any details that help the character to get better as well as the author attempts to make her characters survive. On the other hand, multinarratives technique helps the reader to see himself from another point of view, self-knowledge is a way to survive, as you he sees himself in the mirror, his suffering, his pain that helps to achieve survival.

In all her novels, Atwood refuses to simplify her topics. Every action a character takes has some sort of cost attached to it, psychologically, socially, economically, or even physically, and these costs are thoroughly examined. The depth of Atwood's presentation of the female condition through her novels is astounding. As Atwood's protagonists move toward recognizing and rejecting victimization, their awareness and their decision making processes are exact. Atwood's position on victimization is so thoroughly discussed through its exposition in her novels, that she is as unassailable as possible when she puts forth her platform, as she does in Survival.

The multi styles in Atwood's narrative, in the essence of her fears and warnings for the future, will be given context from the social and political climate of the 1980s. These two approaches are brought to focus on the development of the self in narrative, using the socio-psychological concept of Reflective Self Function, which is a person's capacity to apprehend and understand the motifs for and influences on his or her own behavior and the behavior of others. A central role in self-interpretation 
through interaction is played by narrative (Taylor 1989). It is the means by which we impose order upon the chaotic sense-impressions of life:

"If narrative is taken in its minimalist sense as a representation of at least two events with a temporal ordering between them ... then maintaining awareness of time and space entails creating a minimalist narrative from the continuous ubiquitous multimodal barrage of sensation." (Tversky 380)

By analyzing Atwood's The Handmaid's Tale (1985) the narrative technique is clearly used through its events and lines. This novel points out the concept of storytelling as a mean of resisting and protesting against oppression of Gileaden regime. Atwood depicts the resistance concept in technical style.

The rulers of Gilead regime in the Old Testament is a reaction against abortion, sterilization, and what they consider to be dangerous kinds of freedom of the modem welfare state. The ideal which Gilead's 'Sons of Jacob Think Tank' devised is an imitation of the biblical land of Jacob and Laban, where Jacob restored hope and fertility with the help of a few Handmaids. Thus the regime uses Commanders who subject Handmaids to a monthly penetration in order to solve the problem of excessive and deliberate infertility in the past. The protagonist Offred, who is the Handmaid-slave of the Commander Fred and his infertile wife Serena Joy, is supposed to enact the biblical story of Rachel and Bilhah" Give me children, or else I die. Am I in God's stead, who hath withheld from thee the fruit of the womb? Behold my maid Bilhah. She shall bear upon my knees, that I may also have children by her" (Genesis 30).

Margaret Atwood observes this patriarchal biblical history from the perspective of its female "victims". All the women in Gilead are made to play subsidiary roles, the wives of Commanders included, as well as the elderly infertile women, the Aunts, who save their bodies and souls and who train the Handmaids in self-suppression. Storytelling serves as an important role in Offred's desire to resist Gilead's efforts to erase her individual identity. Her storytelling is deliberately balanced between her narrative of memory and her record of the present centred on her physical environment. Both her external surroundings and more intimately her own bodily experiences "I wait. I compose myself. My self is a thing I must now compose, as one composes a speech. What I must present is a made thing, not something born ". ( The Handmaid's Tale, 25) 
Life does not offer itself to us, as it were, as a pre-formulated story: it has to be made into a story (or rather a whole series of stories) if we are to experience it in any, but the most basic and instinctive manner. The stories we tell ourselves thus provide a critical insight for anyone attempting to develop insights into the human condition, from the clinical psychologist to the social historian. Narratives are, in the most basic sense of the term, works of art and, like all art, everyone finds himself or herself is playing parts in the narratives of others. In other words, people perforce adopt the various social roles allocated to us by those with whom we interact. Others' stories impinge upon our own.

To conclude, everyone pass through many traumatic experiences in his or her life if he submitted to them his or her life will end in a negative way, but if your life ended while you are fighting against these hard conditions it will be a victory for you. As Margaret Atwood says in Survival:

"What a lost person needs is a map of territory, with his own position marked on it so he can see where he is in relation to everything else. We need such a map desperately, we need to know about here, because here is where we live. "Without that knowledge we will not survive." (Survival 27).

Forgiveness is not forgetting or denying one has been hurt. Forgiveness is an acknowledgement that we are human beings who deserve respect (Enright, 2001). Forgiveness involves both psychological and theoretical perspectives. However, according to Enright \& Coyle (1998), "until quite recently, the scientific community has not noticed the link between forgiveness and the alleviation of such distresses as depression, anxiety, hopelessness, and low self-esteem" (p.139). Forgiveness involves three dimensions of human behavior: affective, cognitive and behavioral. Forgiveness involves a process of healing old wounds and making peace with past relationships in order to survive and live a better life and to seek happiness in life .

As a concept, forgiveness has recently received much attention from the popular culture, with books and magazine articles bringing this issue to national attention. Forgiveness can be as an effective coping strategy in helping to reduce stress and resolving feelings of anger, despair, and resentments, which can affect well-being, interpersonal relationships and the quality of life (Konstam, etal, 2002). Emmons Says in Personality and forgiveness (2000) that narrative of life stories helps 
to understand how people make sense of their world and provide their life with meaning and purpose .

Some characters are so filled with self-doubt that they are willing to go along with whatever seems most convenient and socially acceptable. Some exercise whatever the power they have over others in a petty manner, which does them no good and spreads further frustration. The term 'urban decay' sums up these psychological, physical, social, and economic stresses present in the urban environment that reinforce the victimization of women.

There is multi identity for everyone. As Charles Correa in her essay named "Quest for Identity" says "We develop our identity by tackling what we perceive to be our real problem... we find our identity by understanding ourselves, and environment." (10). In her 2003 book, Negotiating with the Dead: a Writer on Writing, Margaret Atwood discusses her position as a writer, specifically in the chapter Duplicity: "The Jekyll hand, the Hyde hand, and the slippery double", " Why there are always two" (29-57). In this chapter, Atwood admits to growing up in a world of doubles which was brought, in part, by the abundance of comic books showcasing the doubles and alter egos of super heroes. She argues that "growing up in this world of doubles aided in the construction of her own self. She cites her two names, her nickname growing up and the one on books, noting that she is both people" (31). Atwood argues that :

all authors have two bodies: one regular and a shadowy personage who shares the same body, and who, when no one else is looking, takes it over and uses it to commit the actual writing. As for the artists who are also writers, they are doubles twice over, for the mere act of writing splits the self in two (Negotiating with the Dead, 35-36).

The aim of the novel is to present their wounded psyche and how they live in that limited society called Gilead. She records her double voice and narrates in order to make a safe place for herself in unsafe Gilead. The confirmation of her voice provokes the unconscious mind of herself by remembrance of the past events and traumatized situation that the commander and his wife have made for her. She suggests multivoices and multi-opinions to find a solution. Although these female characters develop a feminist consciousness in order to transform themselves, Atwood does not like the label 'feminist' for her work unless 
'feminism' as a term is clearly defined in an essay entitled "Her Women suffer,survive" she says:

I'm a feminist ...But on the other hand, do I think that all men should be ... shoved off a cliff? The answer is no. So I think I'm one of those people in between two extremes. I don't think- women should be made to feel incompetent ... or inferior, nor do I think they should be put down for choosing to be married, mothers or flower arrangers. I think if feminism is defined too narrowly, we're going to lose a lot of women. ( 159).

Eco-feminism or ecological feminism is a term coined in 1974 by Françoise d'Eaubonne. It is a philosophy and movement born from the union of feminist and ecological thinking and the belief that the social mentality that leads to the domination and oppression of women is directly connected to the social mentality that leads to the abuse of the natural environment. William Rueckert is considered to be the first one to make use of the term eco-criticism in (1978) in his essay entitled "Literature and Ecology" , "An experiment in eco-criticism aiming to the application of ecology and ecological concepts to the study of literature"(105-123). The uniqueness of Rueckert's eco-criticism lies in emplacement of the patterns surrounding literature to the ecological web.

Cheryll Glotfelty in The Eco-criticism Reader Landmarks in Literary Ecology defines eco-criticism "as the study of the relation between literature and the physical environment (10). This is the most widely established and well liked definition. Lawrence Buell in The Future of Environmental Criticism: Environmental Crisis and Literary Imagination defines eco-criticism "as the environmentally oriented study of literature and arts more generally and to the theories that underline such critical practice"(12). Joyce Nelson says,

"eco-feminism bridges the gap between ecology and feminism: strands of analysis which have existed side by side over past decades without necessarily intertwining. By making explicit the connection between a misogynist society and a society which has exploited mother earth to the point of environmental crisis, Eco-feminism has helped to highlight the deep splits in patriarchal paradigm." (20)

The Eco-feminist theory links the oppression of women with the oppression of nature. More specifically, 
"ecological feminism is the position that there are important connections historical, symbolic, and theoretical between the domination of women and the domination of nature, an understanding which is crucial to both feminism and environmental ethics (Warrem,p.235).

Ecofeminism is a new way of approaching nature. According to Andy Smith eco-feminists are mostly concerned about the oppression of women and the oppression of earth. They believe that the domination of women over the years is directly connected to the environmental rape of our planet. Thus, issues of power, domination and subordination are very vital to ecofeminism. As the term suggests, it is a combination of ecology and feminism. According to Greta Gaard,

"Ecofeminism's basic premise is that the ideology, which authorizes oppressions such as those based on race, class, gender, sexuality and physical abilities, is the same ideology which sanctions the oppression of nature. Ecofeminism theorists consider the interconnections between sexism, the domination of nature, racism, specialism and other social inequalities".(137)

Eco-feminism derives an idea that all living organisms must be seen in relation to their natural surroundings. According to Collins Dictionary of Sociology, " ecofeminism suggests that an end to the oppression of women is bound up with ecological values, and that women should be centrally concerned with ending the exploitation of the ecosystem" (Collard, 1988).

Margaret Atwood has in many of her novels, dealt with the issue of women and nature. In an age of environmental crisis, Atwood takes her writing as a mission to do some good, to ameliorate the crisis. In her works Atwood has performed the function of the artist to speak the forbidden, to speak out especially in a time when progress and development are the jarring jingles of Multi-national Companies that are swallowing up the earth and its resources. The relationship between literature and environment conducted in a spirit of commitment to environmental crisis is obvious in Atwood's novels. Images of nature and aspects of the natural environment have been Atwood's topics. With great craft she weaves together image patterns and themes that draw spontaneous eco-critical attention. Subjugation of woman in a patriarchal 
society and exploitation of nature in a capitalistic society are the themes which Atwood has quite often taken up for her writings.

Margaret Atwood's Surfacing (1972) has received mixed responses from various critics all over the world. Margaret Atwood's teacher, a well known Canadian critic, Northrop Frye calls it" an extraordinary novel, which perfectly represents her own critical review of Canadian themes"(321). Surfacing deals with the collective victim theme of Canada. Margaret Atwood is seriously concerned with the country's plight as a political victim. In this novel, she portrays the relationship between Canada and America. Margaret Atwood has depicted the exploitation of nature and women in her novel Surfacing.

The title of the novel Surfacing is very significant because it reveals the efforts of an individual's self exploration which undergoes many phases of physical troubles and mental traumas. All the efforts of an individual in the novel for self exploration clearly come up on the surface in midst of the nature from deep conflict between self and society and gives a new power of re-thinking and insight to the nameless heroine of the novel for further process of life. Surfacing (1972) is, clearly, a text of its time; influenced by rising second wave feminism and sympathetic to the concerns of ecofeminism and environmentalism, it also reflects the contemporary interest in the kind of national thematic criticism that Atwood exemplifies in her critical text of the same year.

In Surfacing, Margaret Atwood has written about a search for harmony and wholeness in a divided person. The novel is divided into three parts. Part one describes the nature of Canada and presents the characters. The disappearance of protagonist's father and her quest for him is depicted in this part. This section lasts on a note of suspense and the narrator's pretended marriage and divorce and survival of her child. The protagonist rejects her sin of aborted child by fabricating a set-up of trickery and misrepresentation. Part two goes forward to the search of the narrator's missing father. She discovers the truth of her father's disappearance and some awful truth about herself. She admits the truth of her sin. In the third and final section, the narrator moves on from rejection to acceptance. She gets pregnant and believes that her lost baby is surfacing within her to forgive her. At the end of this section the narrator emerges as a total human being and with complete feelings. The usual reasons for treating nature aggressively do not sound right to her anymore. Hence, she becomes aware of her body, which is fragmented 
through her past abortion, as identifiable with that of the fish whose completeness of body she cannot violate by killing.

The nameless protagonist, or the narrator of the novel is an eco feminist.The heroine goes to her birthplace in search of her lost father. She finds the place a "foreign territory". The heroine has deep sympathy towards nature. She finds that her birth place is being violated by Americans and Canadians in the name of civilization and this is leading to environmental degradation. "I'm in the village, walking through it, waiting for the nostalgia to hit" (Surfacing,12). She recognizes the extent to which nature has been victimized by the Americans. Her evolving awareness of herself as a 'victim' is parallel to her recognition of nature victimization as well. Men deteriorate nature and women just for their pleasant. As the renowned ecofeminist Petra Kelly observes, "Women are sex toys for men, women's lives count less than those of men; women who assert their independence and power are in some way defective" (118).

Preserving and protecting the land and ecosystems have always been on Atwood's mind, and Surfacing reflects this concern. Ecological awareness is a constant theme throughout the novel, and the importance of nature in the protagonist's development expresses this newfound perception. A very interesting predecessor for the narrator to think of herself as nature is her mother, though she was primarily under the influence of culture and civilization, the law of the father. Margaret Atwood's Surfacing illustrates the possibility of developing connections between women and nature through an ecofeminism perspective. In her novel, Atwood exposes her protagonist to a self-reflective journey through nature, challenging the stereotypical and biased association of women and nature with inferiority. The protagonist undergoes a deep process of self-analysis throughout her quest. Using the search for her father as an excuse, she sets off on an inner journey to find herself by the end of the novel.

Within this text, power and domination, directly oppress both the feminine world and the natural world. The protagonist realizes the gap between her natural self and her artificial framework only when she encounters nature. The eco-feminist impact is seen implicit in the novel by the protagonist's return to the natural world. Her association with nature raises her consciousness of victimization of women, 
"The trouble is all in the knob at the top of our bodies. I'm not against the head or the body either: only the neck that creates the illusion that they are separate.... If the head extended directly into the shoulders like a worm's or a frog's without that constriction, that lie, they wouldn't be able to look down at their bodies and move them around as if they were robots or puppets; they would have to realize that if the head is detached from the body both of them will die." (Surfacing, p.75)

Like a true ecologist, she makes the earth her home for she knows that in the natural world all life is interrelated, teeming with diversity and complexity. Since the novel introduces an issue pertaining to feminism and environmentalism, the novel constitutes a representative literary example of ecological feminism. Even the language, events and characters in this novel reflect a world that oppresses and dominates both femininity and nature. The oppression of women in a male dominated society and exploitation of nature in a society having new developments in technology, are the major themes of her writings. Within this text, power and domination, directly oppress both the feminine world and the natural world.

The nameless protagonist finds a reflection of her own tragedy in the Quebec landscape. She expresses a deep concern for nature and helps the readers understand the women-nature connection. In the course of her homeward journey she discovers that "nothing is the same. I don't know the way anymore" (Surfacing, 10). Throughout the novel Atwood reminds the readers that ecological destruction pervades the setting whether it is to control the dam or the destruction of older trees: "The trees will never be allowed to grow tall again, they're killed as soon as they're valuable, big trees are scarce as whale." ( Surfacing,55)

In Surfacing the narrator of the story remains nameless throughout the novel. Commenting on the namelessness of the heroine Nancy A. Walker says that "the narrator lacks a clearly defined self that can be named."(79) Being nameless the protagonist says to her friend Anna, "I no longer have a name. I tried for all those years to be civilized but I'm not and I'm through pretending." (Surfacing, 162).It can be said that by depriving her protagonist of a name, Margaret Atwood has been able to suggest that Surfacing is not a story of a particular woman, but of the millions of women all over the world who may identify themselves with her. 
The novel points out the differences between natural predation and the hunting done by the man which is done for the excitement of killing. This contributes to the alienation of modern man from the natural world. As Vandana Shiva points out, it is not hunting which leads to a violent relationship with nature "it is the elevation of hunting to the level of ideology which does so" (Staying Alive, 50). Margaret Atwood draws attention to the fact that "the world is masculine on the whole; those who fashioned it ruled it, and still dominate it today, are men." (Beauvoir, 557)

As Bouson says, through David, "Surfacing draws attention to the oppression of women in a male-defined order of hierarchical and oppositional roles that empower men at the expense of women."(207) Like nature, the female body is also seen as a resource to be colonized and commercialized. The unnamed narrator realizes that as she has been violated, the sacredness of the Mother Earth is violated and the ecological unity, which means the independence of all species, is disturbed. Atwood shows man's misuse and woman's use of nature in Surfacing. The first sentence of the novel indicates the death of white birches, "I can't believe I' $\mathrm{m}$ on the same road again, twisting along past the lake where the white birches are dying, the disease is spreading up from the South, and I notice they now have sea-planes for hire" (Surfacing, 3).

Atwood emphasizes the fact that men exploit the bodies of women for their needs. They even control the process of childbirth which nature has assigned only to women. The unnamed protagonist is betrayed by selfish lover but says, "for him I could have been anyone but for me he was unique, the first, that's where I learned. I worshipped him...I kept scraps of his handwriting like saints' relics..."(Surfacing, p.142). The protagonist also questions the excessive use of reproductive technologies. The novelist has made an attempt to create an emphatic relationship between the wounded self of the unnamed protagonist and the damaged landscape of the island near the border country in Quebec. "At the midway pond the heron was still there, hanging in the hot sunlight like something in a butcher's window, desecrated, unredeemed. It smelled worse the death of the heron was causeless, undiluted". (Surfacing,167)

The unnatural act of her abortion and the continued struggle for her to feel comfortable with words and language illustrate the extent to which society or man oppressed and consumed the surface. Both empowering and dominating nature of her ex-lover shows, "The unborn child was my husband's, he imposed it on me, all the time it was growing in me I felt 
like an incubator. He measured everything he would let me eat, he was feeding it on me, he wanted a replica of himself." (Surfacing, 28). Margaret Atwood is emphasizing the fact that men exploit the bodies of women for their needs. They have controlled the process of childbirth which nature has assigned only to women. Men want women to remain powerless victims. She refuses Joe's marriage proposal "The finality; and he'd got the order wrong, he'd never asked whether I loved him, which was supposed to come first. I would have been prepared for that." (Surfacing,80).

Joe does not realize the need for it because men expect women to be absolutely passive and also because they think marriage is a woman's destiny. The relationship between the protagonist and Joe, offers an interesting insight into male-female dichotomy. The protagonist's acceptance of the partnership is almost fatalistic. She realizes that for Joe sexual need is primary and he wants to dominate and control her. She perceives a killer and victimizer in him.

Margaret Atwood's "Surfacing takes woman as an existential condition, the condition of being powerless and manipulatable." (Jaidev, p.54) Since power is centralized in the hands of man, they feel nothing wrong in destroying her dignity or creativity or even her identity to prove their impact and power over her," the protagonist realizes though belatedly that no human being can help her in discovering her real self and she admits that she suffers from a guilt complex and in the end of the story, she decides to conceive a baby and resolved that, this time I won't let them." (Surfacing, p.187). The narrator decides to prove that the process of childbirth is women's power not men's and a woman can deliver the baby the natural way. She says:

This time I will do it myself.... The baby will slip out easily as an egg, a kitten and I'll lick it off and bite the cord, the blood retiring to the ground where it belongs; the moon will be full, pulling. In the morning I will be able to see it: it will be covered with shining fur, a God. (Surfacing, 156)

Therefore, the protagonist turns to nature. Ironically enough it is only when she identifies herself with the damaged landscape that she discovers herself. "I am not an animal or a tree, I am the thing in which the trees and animals move and grow, I am a place." (Surfacing, 236). Through the struggle to reclaim her identity and roots, the protagonist begins a psychological journey that leads her directly into the natural world. 
The narrator, in the last few pages, sees the natural world as her equal, refuses to fall into the same patriarchal trap that initially destroyed her, and reclaims her ability to trust. Though she does not return to society, she does so as a changed person. She realizes "that human beings are not radically separate from nature: that the fulfillment of our humanity is profoundly linked with learning to appreciate the nature within us and without" (Surfacing, 43)

Despite her fear of the consequences, her search for her missing father and her search for self increasingly offer her the power to resist the oppression inherent in their relationship and to reassess her own need. Margret Atwood seems to be questioning the existing power politics, the traditional notions of male superiority, and the mutilation of women by men. She is trying to assert that women can refuse victimization and can gain transcendence from the male defined world and can hope to breathe freely in a world defined by them. Emma Parker says:

"Her rejection of, and return to [nature] society is reflected by what she eats. When she rejects culture and retreats into the wilderness to become a natural woman, she gives up eating processed food. Such food is contaminated in the same way that society is contaminated by patriarchal ideology. Both are unnatural constructed man made and both threaten to poison her. Instead, the narrator eats only the raw food that nature provides." (350-51)

Surfacing represents the feminine consciousness and shows a woman's struggle to free herself. Her association with the people and Nature raises her consciousness of victimization of woman. When her feminist consciousness reaches its climax, the protagonist makes ready the ground for revolt against exploitation oppression. As Carol Christ says," narrator awakens, from a male-defined world".(325)

At the end she looks for the last time "at the distorted glass face...not to see myself but to see. I reserve the mirror... it no longer traps me. Anna's soul closed in the gold compact, that and not the camera is what I should have broken "( Survival, 175). She resumes her journey alone which finally brings her through extreme hardship to the symbolic plunge and to resurface this time with the defiance never to be a victim any more. The protagonist moves from struggling with the oppression and domination of the male world to associating with various feminine principles and motifs to eventually embracing and returning to the natural world as an equal, unassuming member. Margaret Atwood shows men's 
misuse and women's use of nature in Surfacing. Women's association with fertility and men's with environment abuse specifically as a metaphor of the violation of women by men.

Atwood deals with the theme of abuse of nature and women by the society in most of her novels. Margaret Atwood in Surfacing offers a way to cross the distance among characters true identity and socially or logically fundamental identity through creating a connection between the destroyed landscapes and wilderness of Canadian nature and the injured self of the nameless protagonist in the novel.The protagonist seems suffering from exploitation, pangs of conscience, feeling guilty and alienation in the initiative actions of her journey. However, her awareness and consciousness that there is a great common features and likeness with nature around her, makes it easily bridging the barrier of communication that she makes between herself and the world. As Mrs. R.C. Sheila Royappa states,

she chooses physical isolation a voluntary seclusion from society and gets rid of anything human about herself, becoming more and more like an animal. She moves to a non-verbal level and explores other means of communication.......English words begins to sound "imported, foreign. With the end of her visionary experience, she releases that she is no longer an animal and has become human again, (Mapping Mind, 125).

Through the struggle to reclaim her identity and roots, the protagonist begins a psychological journey that leads her directly into the natural world."I can't believe I'm on the same road again, twisting along past the lake where the white birches are dying, the disease is spreading up from the South, and I notice they now have sea-planes for hire." (Surfacing, 3)

As Charles Correa in her essay named "Quest for Identity" says "We develop our identity by tackling what we perceive to be our real problem...we find our identity by understanding ourselves, and environment."(10). Surfacing (1972) concentrates on this specific theme and gradually manifests the new identity of the protagonist through the deepness of her connection with the Canadian nature. Through the first lines of the novel it's known that the protagonist is on a trip along with her boyfriend Joe and two other friends, Anna and David are in search of her father. She is eager to know why her father has disappeared. 
Her past memories are outraged by her searching journey and she somehow starts connecting herself to the nature surrounding her. The unnamed female protagonist of the novel goes up on a journey or a quest, not only to find out her disappeared father ,but also to rediscover her own missing self and identity and to get rid of her painful emotions. After the occurrence of her abortion, she begins to regard herself as powerless and victimized. She confesses in surfacing about her victimization: "he imposed it on me, all the time it was growing in me I felt like an incubator.. after it was born I was no more use" (Surfacing, 156 ).

So, her journey through the Canadian wilderness is an attempt to reveal the truth about herself and to get the evolution of a new identity free from the society constraints, past memories and male control. She decides to stay on the island alone in order to establish affinity with the nature and bring back her power for recreation:

"I have to recent, give up the old belief that I am powerless and because of it nothing I can do will ever hurt anyone. A lie which was always more disastrous than the truth would have been. The word games, the winning and losing games are finished; at the moment these are no others but they will have to be invented, withdrawing is no longer possible and the alternative is death," (Surfacing, 191).

This protagonist clearly reflects the massive inspiration of an unconscious feminist. She confirms that so long she lives only as a creature, but by connecting with nature she becomes a nature-creature. She discovers complete harmony with the Canadian Wilderness. When she decides to stay on the island in isolation, she gets closer to nature and her female body is transformed into plants, animals, insects etc. In brief, her identity is transformed. Her journey from the city to wilderness can be regarded as a journey of trans-personalization to a new revelation that allows the nature to become part of her female body. By taking off her cloths, symbol of civilization, she becomes one with nature only to transform herself into a matured and conscious human being.

The protagonist dives deep into the water of the lake and emerges or surfaces with the power of becoming victorious and optimistic in life breaking the assumptions of her powerlessness. The new transformed self of the protagonist can be explained in a precise manner in the words of M.F. Salat:

"Hence when the protagonist surfaces from the depths of the lake, she surfaces with a new knowledge about herself that 
entails a re-assessment of herself in relation to the world. The psychological/spiritual journey towards self-discovery finds its culmination in a ritualistic re-alignment with the primitive world and a subsequent re-alignment with the lived world with altered perspective and a new vision." (82).

The protagonist involves a real eco-feminist prospect by asserting that: "human beings are not radically separate from: nature: that the fulfillment of our own humanity is profoundly linked with learning to appreciate the nature within us and without" (Surfacing,40).

Her connection with nature evokes her consciousness of victimization of women. When her feminine consciousness reaches its climax, the protagonist makes the surface ready for revolt against abuse and exploitation. She revolts as a kind of revenge. The power struggle seems to have come to an end. She feels so confident about her own power and refuses to be a victim and says, "This above, all, to refuse to be a victim". ( Survival, 249). She decides to stay back in Quebec and give birth to the gold fish nurturing in her womb. She does not know the child gender in her womb but has made up her mind to assert herself by allowing the fetus to grow. She says, "I cannot know yet; it's too early. But I assume it: if I die it dies, if I starve it starves with me. It might be first one, the first true human; it must be born, allowed" (Surfacing, 250). The woman-nature connection by erasing the distinction between the two reveals the truth that both nature and men have the mystical power to drive away all the damages both in psychological and physical levels and to restore the true power of humanity by becoming one with nature.

The novelist has made an attempt to create an emphatic relationship between the wounded self of the unnamed protagonist and the destroyed landscape of the island near the border country in Quebec. Her journey to Quebec with her three friends made her see into the life of things and in the process she gets away from all- her friends as well as the people who indulge in senseless cruelty to birds, trees and fish, "At the midway pond the heron was still there, hanging in the hot sunlight like something in a butcher's window, desecrated, unredeemed. It smelled worse the death of the heron was causeless, undiluted." (Surfacing,167)

She realizes though belatedly that no human being can help her in discovering journey to discover her real self and, therefore, she melted with nature. Ironically enough, it is not only when she identifies herself with the damaged landscape that she discovers herself. She becomes part 
of the landscape but prior to this, she discards her marriage ring, her name and her seeming identity. In her healing process, the narrator begins to compare herself with the dead heron, The brutal and unnecessary murder of the heron presents a direct ecological parallel to the experience of the narrator. According to Rigney," The protagonist sees the heron as symbolic of her own psychological death" (Madness and Sexual Politics,100). The power for destruction can be reconciled only with the power for creation. She gradually comes to feel that she herself has been anti-nature. She had tried to subvert nature by getting the fetus aborted. So, she must compensate for this anti-nature activity. So she decides to bear a child and allow the baby to grow as a natural human being in the most natural way,

This time I will do it myself . . the baby will slip out easily as an egg, a kitten and I'll lick it off and bite the cord, the blood returning to the ground where it belongs; the moon will be full, pulling. In the morning I will be able to see it, it will be covered with shining fur, as god, I will never teach it any words. (Surfacing,209)

When she connects her own life with those of the other creatures in nature, she is able to comprehend the rhythm of nature its cycle of life and death. She gets the conclusion that in order to merge with nature; she has to spill her clothes to become like the victim animals. She survives on mushrooms, plants and berries. She connects with the forest, descending even further to the level of plants. After linking her life with the natural things, she feels that her life has been totally changed. She feels:

Through the trees the sun glances; the swamp around me smoulders, energy of decay turning to growth, green fire. I remember the heron; by now it will be insects, frogs, fish and other herons. My body also changes, the creature in me, plant-animal, sends out filaments in me, I ferry it secure between death and life, I multiply. (Surfacing,217)

Like a true ecologist, she makes the earth her literal home, for she knows that in the natural world all life is interrelated, full of diversity and complexity. She is not scared .She is safe enough in the nature. There is no one to boss her over and violate her physique. She becomes one with her sacred Mother Earth. She throws away all her civilization as it is destroying the biosphere. She may recreate a culture that respects to seek harmony with nature. Those whom she has known are living in the city 
now, in a different time. She remembers her man, "fake husband for whom she now feels nothing but sorrow. She totally relies on Mother Earth. Gods are questionable to her; it includes even Jesus Christ who is to her theoretical ( Surfacing,247).

Since the novel elaborates an issue pertaining to feminism and environmentalism, the novel constitutes a representative literary example of ecological feminism. Even the language, events and characters in this novel reflect a world that oppresses and dominates both femininity and nature. This actual journey is the surface meaning while the deep meaning lies in the journey of self-discovery and assertion of her individual identity. These two kinds of meanings links ecology with feminism and make the novel an eco-feminist novel. However, she does not want to overturn patriarchy and replace it with women's dominance. She wants to transform nonviolently the structures of male dominance and restore a kind of balance and harmony between women and men. However, the conception of a new baby seems to offer healing. The surface has gone through a cycle of grief, and eventually arrives at the final stage: acceptance. The process is mirrored in her observation of a fish:

From a lake a fish jumps An idea of a fish jumps A fish jumps, carved wooden fish with dots painted on the sides, No, antlered fish thing drawn in red on cliff stone, protecting spirit. It hangs in the air suspended, flesh turned to icon, he has changed Again, returned to the water. How many shapes can he take. I watch it for an hour or so: then it drops and softens, the circles Widen, it becomes an ordinary fish again. (Surfacing,181)

This scene which she is affected with, seems to have many interpretations itself-all of which reflects human inversions, its looks like someone looking at the mirror to see her own life journey. The fish has travelled through many different forms, but in the end it remains-or returns to being a fish. Likewise, she has been through many transformations but ultimately becomes an ordinary human again. This marks the point at which she seems ready to return to civilization with a new identity.

Atwood's protagonist is never named in the novel and it is often referred to by critics as "the surface". Atwood generalized the idea of exploitation of women and nature. So the unnamed protagonist refers to every traumatized women and exploited nature. The character undergoes a significant metamorphosis during the novel and apparently seeks to 
discard her identity as a human being and to assume that of an animal. The surface travels, with her partner, Joe, and another couple, David and Anna: journeying from the city into the wilderness in which she grew up whilst the trip is ostensibly undertaken in order for the surface to investigate the disappearance of her father. It is obvious that her reasons are truly more personal, and not yet clear to her. "discovered people could say words that would go into my ears meaning nothings".(Surfacing,5)

One significant issue is that the narrator struggles for her inability to feel her absolute lack of emotion. This is obviously a psychological effect of the abortion. The detrimental effects and feelings of alienation that occur from having abortion have been documented and substantiated by psychiatrists. Her abortion caused her to feel cut off from humanity and her failed affair has resulted in her inability to love, as Quigley points out:

Loving had brought such pair; she would not love again. Trusting a man had brought about mutilation, the violation of motherhood and nature. She had compared a divorce to an amputation, when in fact the amputation, her abortion, had caused the divorce, not only from her lover, but from all love, all feeling. (83)

Thus Atwood's Surfacing takes readers below the surface through woman life who re-visits her childhood home and the secrets and memories of the past. Many of Atwood's novels delve into the theme of finding one's self. Most of the time, the narrator on this self-journey is a female. Surfacing leads her down a path of self discovery madness, of animalistic desire and of extreme confusion. The quest for self-identity begins with a trip to the unnamed narrator's childhood cabin with her lover and a married couple, in search of some answers surrounding her father's recent and mysterious disappearance. The narrator spends some time looking around the cabin and the woods for some clues but she comes up empty. Once the surface is scrapped for answers, the readers are taken deeper into the story, both past and present.

The map she discovered maybe considered as a clue to find her missing father as her missing identity as well. She has to dive deep underwater to find hidden rocks marked on it. Instead, she re-discovers her past and the truth about a shocking occurrence that has left her damaged emotionally and mentally. Her past still lingers deep within her, causing her to deceive herself and others around her. Unfortunately, once the truth has been re-surfaced, the narrator's quest leads her into a type of 
madness where she rejects society and human company and instead melts with the nature.

Margaret Atwood's Cat's Eye (1988) is a novel about the nature of memory and identity. Elaine Risley is aware of how uncertain memory can be, and how our present life is colored by past events. As Risley discovers her talent as a painter and reflects her past experiences through creative paintings . Also, the novel provides a vivid image of Toronto in the 1940s and 1950s, and points out how totally the city had changed by the 1980s. In Cat's Eye, Atwood treads similar ground, tracking the passage of its protagonist painter, Elaine Risley, through her childhood time in mid-century in Canada to her development as an proven artist in the 1980s. By going through the novels it is clear that it deals with the notion of identity. Elaine's, as she returns back to Toronto to attend a retrospective of her work at a women's art gallery named "SubVersions", "Until we moved to Toronto I was happy"( Cat's Eye,22). She is forced to experience not only a visual retrospective in the form of her paintings but, on a larger scale, an emotional and psychological retrospective of her life, a mental journeying back into her past.

The narrative framework of Cat's Eye (1988) is mainly about the idea of the retrospective, it shifts back and forth, from past to present, moving from the 1980s to Elaine's childhood in the 1940s, tracing her life journey. Throughout the novel, Atwood's protagonist uses her recovered past events in order to justify reasons why she becomes the person who exists in the present time, alienated from others, she finds that her disturbed past works as a painfully accurate mirror for her whole life in the present and middle age. By the introduction of the novel as unfriendly relationship with a woman named Cordelia, a childhood terrifying character, who relentlessly torments the young Elaine and, later in life, their relationship improved to be a fragile friendship,

There are days when I can hardly make it out of bed. I find it an effort to speak. I measure progress in steps, the next one and the next one, as far as the bathroom. These steps are major accomplishments. I focus on taking the cap off the toothpaste, getting the brush up to my mouth. I have difficulty lifting my arm to do even that. I feel I am without worth, that nothing I can do is of any value. least of all to myself. What do you have to say for yourself? Cordelia used to ask. Nothing, I would say. It is a word I came to connect with myself, as if I was nothing, as if there was nothing there at all.( Cat's Eye,49) 
Their relationship becomes a catalyst for a larger debate of the shifting and relative nature of identity for Atwood's protagonist as both an artist and a woman. The excessive use of mirror is so clearly outlined in her earlier work, Survival, Atwood's Cordelia, a part friend, forms a mirror for Elaine throughout her life, prompting her to question her identity and representing a cruel kind of reflection for her developing childhood self:

Cordelia brings a mirror to school. It's a pocket mirror, the small plain oblong kind without any rim. She takes it out of her pocket and holds the mirror up in front of me and says, "Look at yourself! Just look!" Her voice is disgusted, fed up, as if my face, all by itself, has been up to something, has gone too far. (Cat's Eye,158)

In Cat's Eye, apparently a book about the issue of childhood terrifying but it has excessive meanings beneath the surface .Atwood uses excessive images to portray Canada and how it was in the past. She tries to elaborate how it moves away from its identity as colonized affected by outsiders squeezed between two great Western cultural super-powers, Canada is, like Elaine, trying to assert some sort of voice, "What do you have to say for yourself? Cordelia used to ask. Nothing, I would say. It was a word I came to connect with myself, as if I was nothing, as if there was nothing there at all". (Cat's Eye,41)

"This is the middle of my life", asserts Elaine at the beginning of the novel (Cat's Eye,13) as she sees herself being pulled down into the muck and mire of her memories in Toronto,"In my dreams of this city I am always lost" (Cat's Eye,14). Through Cat's Eye, Atwood conducts her own retrospective,

Time is not a line but a dimension, like the dimensions of space ... I began then to think of time as having a shape, something you could see, like a series of liquid transparencies, one laid on top of the other. You don' t look back along time but down through it, like water. Sometimes this comes to the surface, sometimes that, sometimes nothing. Nothing goes away.( Cat's Eye, 3).

At the beginning of the novel, Atwood deliberately locates Elaine's early childhood development outside of the city, in the surrounding wilderness, a wild zone without modern amenities like television, movies or kitchen appliances. Even the Dick and Jane workbooks her mother 
uses to teach her how to read, with their images of suburban middle-class life, strike Elaine as completely foreign: "Nothing in these stories is anything like my life. There are no tents, no highways, no peeing in the bushes, no motels" (Cat's Eye,29); “...we didn't really live anywhere; or we lived in so many places it was hard to remember them" (Cat's Eye, 21).

Cordelia's family aims hard to achieve middle class sophistication in the form of perceived or stereotyped imitations of English life. Her interchangeable older sisters, Perdita and Miranda, are both named after women from Shakespeare's pastoral romances, while Cordelia's name comes from a tragedy. Both shorten their names to "Perdie" and "Mirrie", claiming the names as their own. But Cordelia refuses to make the same allowances as her sisters:

Cordelia ought to be Cordie, but she's not. She insists, always, on being called by her full name: Cordelia. All three of these names are peculiar; none of the girls at school have names like that. Cordelia says they're out of Shakespeare. She seems proud of this, as though it's something we should all recognize. "It was Mummie's idea," she says. (Cat's Eye,73).

Sharon Rose Wilson writes about the role of feeling in Atwood's narratives, "In order to free themselves from the restricting roles of fairytales, comics, television, the Bible, history, and myth and heal their split identities, Atwood's characters and personae must recover feeling" (298). The new versions of women who have been explored in this thesis reveals that they are not the "ideal" or the "best" women. They are new by being a rebel against the general current of the patriarchal society and in exploring her true potential, along with "the struggle to fulfill her urges and needs" (Cat's Eye,14). The survival theme thus establishes a Canadian woman's quest and vision. Their new identities would help them to survive patriarchy neither as a victim nor as a victimizer, not even as a victor, but as an equal survived ones.

Thus Atwood's concentration is based on emancipatory practices on creative non-victim positions, on the articulation of alternatives and opposition. Her novels offer positive visions of female futures, despite of their similar negative pasts, through a mature acceptance of the pain of living and of having lived. Atwood's feminist thought is positively prowoman and not anti-man. It seeks to offer a life-affirming, survivalist, and human rights approach for placing women on equal footing with their 
male-counterparts. Atwood in her novels seeks happy endings for her victimized female figures, So through rituals of survival, they achieved their survival whether psychologically or psychically, which consequently leads to their happiness by their new life perspective.

Atwood's protagonists struggle to realize why they are dissatisfied with their lives and the world around them. They cannot adapt easily with the society around them. Some go beyond realization of victimization, others try rejection, and some miss but most survive. All of them use one common factor which is creativity. They do not need any conventional heroes or do not implement any extraordinary actions. All of them are women in typical victimized situations who refuse to accept their victimization and do what they can to fight this situation.

In fact, her victimized protagonists are all suffer from specifically female issues as well as other oppressive issues. Many of the struggles that they are suffer from are strictly feminine struggles; the nameless protagonist from Surfacing is haunted by her abortion. Elaine Risley in Cats Eye is affected badly by her desire to be accepted in women's society. Rennie Wilford in Bodily Harm has had a mastectomy and Offred in The Handmaid's Tale is objectified by the mere fact that she has "viable ovaries." These women struggle because they are female figure in the male dominate society. In order to survive, they need to recognize the inequalities of their societies, and to resist societies expectations and to control their lives and create their own desirable life

Atwood's strategy depends on creating female protagonists who, each in her own way, find their creative means to seize the metaphorical pen and conquer their fear of being victims. The unnamed protagonist in Surfacing uses pictures to reconnect to her past and find new identity through nature. Elaine Riley's pen takes the form of paintbrush, which she uses to create meaningful paintings depicting her past experiences. Rennie Wilford insists on being an important journalist and write about important and remarkable issues. Offred finds her rejection in voice and get the ability to speak out by narrating her survival tale. By giving her fictional characters the chance to create their own survival, Atwood create successful figures in society able to regain their lives back and continue on their lives as non victimized figures . 


\section{$\underline{\text { Works Cited }}$}

\section{Primary Sources}

Atwood, Margaret. Cat's Eye. Toronto: McClelland and Stewart, 1988

--. $\quad$ Surfacing. London: Virago Press. (1972).

--. $\quad$ Bodily Harm. 1981. London: Virago Press Ltd., 1983

--. $\quad$ Life Before Man. 1979. London: Virago Press Ltd., 1982.

--. $\quad$ The Handmaid's Tale. 1985. London. Virago Press Ltd., 1987

\section{Secondary Sources:}

\section{Books}

Atwood, M., Survival: A Thematic Guide to Canadian Literature. Toronto:

House of Anansi Press Ltd. 1972.

Beauvoir, S., The Second Sex, Tr. \& Edited by H.M. Parshley. Penguin Books, 557 (1949).

Bouson-Brooks, J. Brutal Choreographies. Oppositional Strategies and Narrative Design in the Novels of Margaret Atwood. Amherst: The University of Massachusets Press, 1993.

Christ, Carol P. Margaret Atwood: The Surfacing of Women's Spiritual "Quest and Vision", Signs: A journal of Culture of Women and Society,2.2 Winter 1976,325

Correa, Charles. "Quest for Identity". Architecture and Identity, edited by Robert Powell. Singapore: Concept Media/Aga Khan Award for Architecture, 1983.

Emmons, R. A. (1999). Personality and forgiveness. . In: M.E. McCullough, K. I.,Pargament \& C. E. Thoresen (Eds.), Forgiveness: Theory, Research, and Practice, pp.156-175 New York: Guilford Press.

Enright, R. D. (2001). Forgiveness is a choice: A step-by-step process for resolving anger and restoring hope. Washington, DC: American Psychological Association.

Frye, Northrop. "Conclusion", Literary History of Canada: Canadian Literature in English, $2^{\text {nd }}$ ed. Carl F.Klink, III. Toronto: University of Toronto Press, 1976,321.

Glotfelty, Cheryll ; Fromm, Harold (eds.) The Ecocriticism Reader: Landmarks in Literary Ecology. Athens: University of Georgia Press, 1996.

Jaidev, Problematizing Feminism, Feminism and Recent Fiction in English, ed. Sushila Singh, New Delhi: Prestige Books, 54 (1992).

Jary,David and Julia Jary,Collins Dictionary of Sociology,Harper Collins Publishers, Westerhill Road,2000.

Joyce,Nelcon."Speaking the Unspeakable", Canadian Forum, March 1990.

Kelly, Petra. "Women and Power". Ecofeminism: Women, Culture, Nature. Ed. Karen J. Warren. Bloomington and Indianapolis: Indiana University Press, 1984, 112-119. 
Palumbo, Alice Marie. "The Recasting of the Female Gothic in the Novels of Margaret Atwood." Dissertation Abstracts Intemational, Section A: The Humanities and Social Sciences 60(10) (2000 April): 3660

Parker, E., "You Are What You Eat: The Politics of Eating in the Novels of Margaret Atwood" , Twentieth Century Literature, 41, 3, 350-51, (1995)

Rigney, Barbara H. Madness and Sexual Politics. Madison: University of Wiscousin Press, 1978.

Royappa, R.C. Sheila, "From cadence to Confidence: Mapping the Mind of Margaret Atwood's Protagonist in Surfacing", Canadian Literature: An Overview(ed), Balachandran Dr. K. New Deohi: Sarup and Sons

Rueckert, William (1996) "Literature and Ecology: An Experiment in Ecocriticism," in Glotfelty and Fromm (1996): 105-123.

Salat,M.F Canadian Novel: A Search for Identity. Delhi:B.R Publishing corporation ,1993.

Smith Andy, "Ecofeminism through an Anticolonial Framework". Ecofeminism: Women, Culture, Nature. Ed. Karen J. Warren. Bloomington and Indianapolis: Indiana University Press, 1984, 21-37.

Stewart, G.A., New Mythos, The Novels of the Artist as Heroine 1877-1977, Montreal, Canada: Eden Press, Women's Publication, 156, (1981).

Shiva, Vandana. Staying Alive: Women, Ecology and Survival in India. New Delhi: Kali for Women, 1998.

Taylor, Charles (1989) The Sources of the Self Cambridge: Cambridge University Press.

Tversky, Barbara (2004) "Narrative of space, time, and life" Mind and Language 19/4 pp. 380-392.

Walker, N.A., Feminist Alternatives: Irony and Fantasy in the Contemporary Novel By Women, Jackson: University Press of Mississippi, 79, (1990).

Warren, "The Power and the Promise of Ecological Feminism",. Environmental Ethics, 235.

Wilson, Sharon Rose. Margaret Atwood's Fairy-Tale Sexual Politics. Jackson: UP of Mississippi, 1993

\section{Articles}

Atwood's papers (box 159). Judy Kiemesrud, "Her women suffer, survive, " New York Times II Apr. 1982.

Konstam, V., Marx, F., Schurer, J., Harrington, A., Lombardo, N. E. \& Deveney, S.(2000). "Forgiving: What mental health counsellors are telling us", Journal of Mental Health Counselling, 22(3), 253-267.

\section{Online sources}

Gaard, Greta. Ecofeminism: Women, Culture, Nature, www.asle.umn.edu/pubs/collect/ecofem/Glotfelty.pdf.

Mapp, Christopher Michael, "The relationship between forgiveness, imagined interactions, empathy and relational satisfaction among 
long-distance romantic couples" (2013). LSU Doctoral Dissertations.

827.http://digitalcommons.lsu.edu/gradschool_dissertations/827

9 : 6 June 2009 Pauline Das, Ph.D. The Politics of Survival in the Novels of Margaret Atwood. Language in India www.languageinindia.com 
